\title{
Indicators of Long-term Sustainability and Development of Small and Medium-sized Enterprises in Russia
}

\author{
Liudmila V. Gantseva \\ Department of Management \\ Financial University under the Government of the Russian Federation \\ Moscow, Russia \\ LVGantseva@fa.ru
}

\begin{abstract}
Small and medium-sized business plays an important role in the economy of any country. It is involved in the creation of jobs and production of goods \& services that make our life more comfortable (for example, the sector of trade) [1]. The role of medium-sized business is more significant - in creating innovative growth due to the larger scale of production and its representation in areas of an innovative nature (for example, information technology). Small and medium-sized enterprises (hereinafter referred to as SMEs), due to their mobility, can play the role of a growth driver in an unstable economic situation. That is why it is so important to maintain the sustainability of SMEs, ensuring not only their quantitative growth, but also contributing to their sustainable quality development.
\end{abstract}

Keywords: entrepreneurship, small and medium-sized enterprises, quality development, sustainability, strategy, target indicators.

\section{INDICATORS OF RECENT SMES DEVELOPMENT IN RUSSIA}

The results of the formation and development of SME business in Russia in recent years [2] indicate that, most likely, the first stage in the formation of SME business in Russia was successful. It is reflected in the following indicators:

- By 2019, in the World Bank's Doing Business ranking, Russia moved to 31st place [3] from 124th place in 2010.

- As of September 1, 2018, there are more than 5.92 million [4] SME entities that create jobs for 19 million citizens [2].

- In 2017, the contribution of the SME sector to Russia's GDP amounted to $22.3 \%$ (for comparison, the share of SMEs in the GDP of Canada, Japan, South Africa, and Great Britain is more than $50 \%$ [4]).

- In 2017, 34\% of SMEs increased the indicator of income or the average number of employees [5].

- In 2016, a long-term strategic planning document was approved - the Strategy for the Development of Small and Medium-Sized Enterprises in the Russian

- Federation for the period up to 2030 [6] (hereinafter - the Strategy), which provides the main indicators of the SME sector by 2030 .

- In 2015-2017 the administrative burden on SMEs has been reduced (for example, the frequency of inspections) and measures are constantly being taken to increase the availability of financial resources for SMEs.

- Credit and guarantee support is provided by the Federal Corporation for the Development of Small and Medium Enterprises.

- The volume of lending in the SME sector is gradually recovering (in 2016 the amount of attracted financing under the National Guarantee System was 2 times higher than this indicator in 2015) [2].

- A quota of $18 \%$ was established for purchases of goods, works, services by state companies from SMEs, and the range of purchases was increased exceeding 150 thousand items in 2017 [2]. 
- Uniform support standards are being introduced and the requirements for the activities of all types of support infrastructure are being unified.

- Cooperation continues on the basis of the "one-stop shop" principle in order to provide entrepreneurs with access to services, services, and support measures (for example, at the end of 2017, the MFCs for rendering state and municipal services for businesses are operating in 39 regions [2]).

- In 2016, the volume of turnover of SMEs subject to inflation increased by $15.5 \%$ compared to 2014 [1].

- $\quad$ Over the same period, SMEs began to invest by $21 \%$ more in fixed assets [1].

- At the level of subjects, a national rating of the state of business is calculated, which characterizes the efforts of regional authorities to create favorable conditions for doing business in Russian regions (in 2018, 78 regions showed an increase in the rating) [7].

- Institutionalization of the SME sector is developing: for example, a special Government Commission on Competition and Development of Small and Medium Enterprises has been created [8].

- In 2015, the State Institute for the Development of SMEs was created - the Federal Corporation for the Development of Small and Medium Enterprises [9].

- Some issues of SME support were included in the list of priority measures implemented by the Government of the Russian Federation in 2015-2016 to ensure the sustainable development of the economy and social stability (the support for self-employment and the realization of investment potential, the provision of subsidies for reimbursing the costs of doing business, microloans, loan guarantees or loans on preferential terms, special tax regimes, access for enterprises to purchase goods, works, services for state and municipal needs).

- Expanded information and marketing support for SMEs by the SME Business Navigator Portal (a mobile application was launched for 172 cities with a population of more than 100 thousand people) [10].

- All normative legal documents were adopted, implemented and are under monitoring including

- "Development of competition and improvement of antitrust policy", "Optimization of registration procedures for legal entities and individual entrepreneurs" [11].

- About 700 competence centers have been opened that provide comprehensive services for enterprises at various stages of business development (83 guarantee organizations, 183 microfinance organizations, 66 business support centers, 22 social innovation centers, 54 export-oriented SME support coordination centers, 4 national art crafts, 143 business incubators, 25 objects of industrial parks and technology parks, 121 organization of support for SMEs in the field of innovation and industrial production) [5].

- In 2016, 17 thousand services were provided on a gratuitous and preferential basis (including services for assessing technological readiness of production, technical auditing, automation of management systems and reducing costs for SMEs as part of the organization of their activities) [5].

- In open and operating business incubators, more than 2 thousand of SMEs are located, for each subject an average of 36 units (with jobs about 10 thousand and with an annual turnover of about 10 billion rubles) [5].

- At the beginning of 2017, 1,062 entrepreneurs were located in open industrial parks and technology parks (with a total number of employees of 16,633 people and an annual turnover of 50.7 billion rubles for 2016) [5].

- In 2017 , the number of export support centers increased by 23 units and amounted to 54 centers [6]. 
- For 2016-2017, 279 trainings were conducted and 4863 people were trained in the training programs for SMEs in 62 Russian regions $[4 ; 5]$.

- The educational project "Mom Entrepreneur" provides an opportunity to undergo free training with immersion in the business environment, development of business plans and mentoring support for women on maternity leave, mothers of minor children, as well as women registered with the employment service.

- In 2016, the share of SMEs that applied for services and advice to export support centers amounted to more than $40 \%$ of the total number of SMEs engaged in export activities in the Russian Federation [5].

These results reflect to a greater extent the quantitative growth of small and medium-sized entrepreneurs in our country and do not affect its qualitative side. If we turn to the document on long-term planning for the development of the SME sector - the Strategy, then in the areas of implementing its tasks issues of sustainability are not called directly, everything is aimed at increasing the number of SMEs. The Strategy says so that its mission is to create a globally competitive, flexible and adaptive modern economy that provides the tasks reflected in Fig. 1.
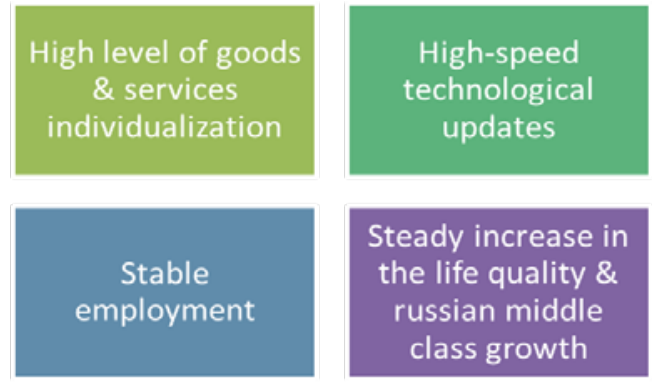

Fig. 1. Tasks of the modern economy for the development of SMEs

The basic principles for the implementation of the Strategy, stated in its document, also speak of an emphasis on creating the sphere of SMEs and do not reveal the issues of its sustainable development (Fig. 2).

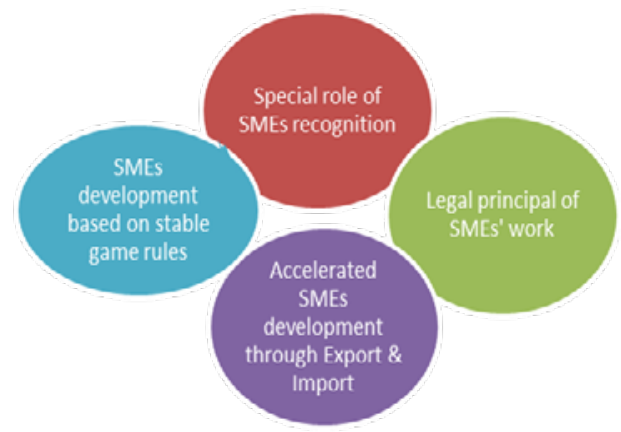

Fig. 2. Tasks of the modern economy for the development of SMEs 
Although it should be noted that the description of these principles also includes the mention of investment plans and business development plans for the medium and long term, which, of course, can be attributed to tools that are partly aimed at maintaining long-term sustainability. However, sustainability issues are not directly stated as topical and priority, thereby reducing their significance.

\section{INDICATORS OF AREAS FOR SMES IMPROVEMENT IN RUSSIA}

- It cannot be denied that at the initial stage it was logical to stimulate firstly the creation of such organizations, providing them with the appropriate infrastructure, which was done. However, at the development stage, attention should also be paid to the issues of financial stability of such companies, thus ensuring the creation of a pre-healthy community with a competitive infrastructure. Moreover, in terms of quality characteristics, there are areas for improvement, as evidenced by the following data:

- $\quad 95 \%$ of the total number of SMEs in Russia are microenterprises, where on average one employee is employed [7], that is, those entities that can contribute to the productivity and innovative development of the economy by their scale are still very few.

- The share in the total volume of exports by SMEs is a small amount $-6 \%$; in the total volume of non-oil exports $-9 \%$ [2]

- In Russia SME businesses provide only $25 \%$ of permanent jobs, while in developed countries this indicator ranges from $35 \%$ to $80 \%$ [4].

- The concentration of SMEs in Russia is different: $45 \%$ of the total number are represented in 10 Russian regions [2].

- A low proportion of citizens starting a business - only $4.7 \%$ [2].

- In 2017, the share of gross value added of SMEs (including individual entrepreneurs) in the GDP of our country decreased by $0.7 \%$ compared to 2016 after a rapid increase by $4 \%$ in 2015 compared to 2014 [4].

- Only in 31 Russian regions the basic infrastructure for SME support has been formed (business support center, guarantee fund, microfinance organization, property support infrastructure for beginners and existing entrepreneurs, centers of competence in the innovation and production sphere) $[4 ; 5]$.

Thus, we believe that the near-term priority tasks should contribute to the sustainability and effectiveness of SMEs, so that further market growth is also accompanied by their stability. The Strategy document, which also analyzes the causes of the inefficiency of SMEs, can help us with this, including the factors indicated in Fig. 3.

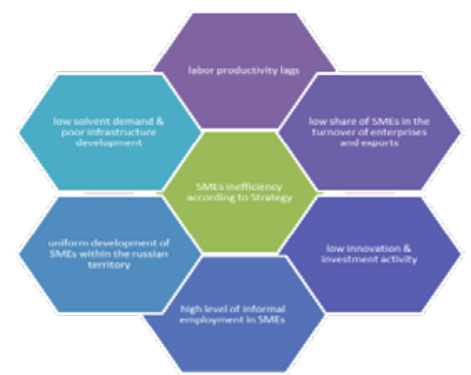

Fig. 3. Reasons for the inefficiency of SMEs in Russia

These factors are a brake on increasing the market for products, increasing profitability and ensuring the transition of enterprises from microbusiness to small or medium-sized businesses. In addition, due to the specialization in trade and related operations, small enterprises almost do not participate in innovation, since the trade sector does not pose a demand for the creation of technological innovations. As a result, confidence [12] in the quality of products and services of SMEs remains low. 
Based on the foregoing, the factors and barriers to the development of SMEs in our country include the factors reflected in Table 1.

Table I. Criteria and barriers for the development of smes in Russia

\begin{tabular}{|l|l|}
\hline \multicolumn{1}{|c|}{ Sustainability criteria } & \multicolumn{1}{c|}{ Development barriers } \\
\hline $\begin{array}{l}\text { Constant state support } \\
\text { at all levels of the } \\
\text { Government }\end{array}$ & $\begin{array}{l}\text { Lack of sustainable development targets } \\
\text { in the long-term legislative framework } \\
\text { documents }\end{array}$ \\
\hline $\begin{array}{l}\text { Sustainable profitability } \\
\text { of SMEs }\end{array}$ & $\begin{array}{l}\text { Lack of qualified specialists, constantly } \\
\text { improving their knowledge and skills }\end{array}$ \\
\hline $\begin{array}{l}\text { The ability to access } \\
\text { investment in order to } \\
\text { modernize production }\end{array}$ & $\begin{array}{l}\text { Underdeveloped SME support } \\
\text { infrastructure }\end{array}$ \\
\hline $\begin{array}{l}\text { Opportunity to receive } \\
\text { advice and advanced } \\
\text { training for SME staff }\end{array}$ & $\begin{array}{l}\text { Difficulties in maintaining their market } \\
\text { position (highly dependent on market } \\
\text { fluctuations) }\end{array}$ \\
\hline $\begin{array}{l}\text { Stable demand for } \\
\text { products/services }\end{array}$ & $\begin{array}{l}\text { Difficulties in obtaining financing for } \\
\text { development }\end{array}$ \\
\hline
\end{tabular}

For each listed condition/barrier, a separate detailed program for its implementation/elimination can be developed. We believe that the priority should be the definition of sustainable development targets in the long-term documents of our legislative framework, that is, in the Strategy.

How can the tasks of sustainability be fixed in the Strategy? Many tasks of the SME business developing in Russia are solved by setting targets, which are designated in the Strategy as basic indicators, the achievement of which is expected in in 2030 (Fig. 4).

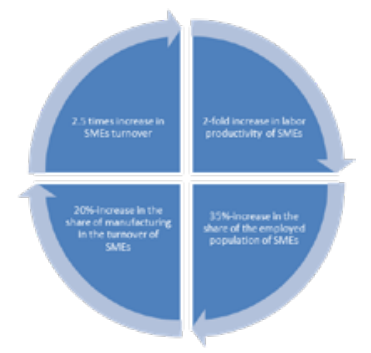

Fig. 4. The targets for the development of SMEs declared in the Strategy until 2030

\section{TARGET INDICATORS OF SMES SUSTAINABILITY IN RUSSIA}

As we see, sustainability issues in the target indicators of SME development are not stated in the Strategy, everything is aimed at creating the appropriate infrastructure for SMEs. So, the target indicators for the implementation of the Strategy are represented by various indicators of the turnover, number of employees, volume of purchases, the share of loans to SMEs, the emergence of new entities. The only section that can be related to sustainability issues relates to technological development: productivity of jobs in SMEs and its growth; export of SMEs and its shares in the total exports of the Russian Federation; the development of SMEs in single-industry municipalities and the share of funds allocated for its support from the federal budget. 
In our opinion, such indicators are not enough and their list can be supplemented with new indicators. The groups of such indicators could be just those that determine the conditions and barriers for the development of SMEs from Table 1, including indicators of stimulating demand for the products of such entities, training and the exchange of best practices for providing knowledge in this area. These provisions are stated in the Strategy as priority areas, but are absent in the target indicators. Examples of targets with which we propose to supplement the targets of the Strategy are presented in Table 2:

Table II. Targets for sustainability of SMEs

\begin{tabular}{|c|c|}
\hline $\begin{array}{c}\text { Indicator } \\
\text { groups }\end{array}$ & Groupmetrics \\
\hline $\begin{array}{l}\text { SME } \\
\text { Infrastructure } \\
\text { Development }\end{array}$ & $\begin{array}{l}\text { - Annual increase in the number of SMEs located in open and operating } \\
\text { business incubators; } \\
\text { - annual increase in the number of entrepreneurs in open industrial } \\
\text { parks and technology parks; } \\
\text { - annual increase in the number of established export support centers; } \\
\text { - annual increase in the number of services provided for the assessment } \\
\text { of technological readiness of production, technical audit, automation } \\
\text { of control systems and cost reduction for SMEs }\end{array}$ \\
\hline $\begin{array}{l}\text { SME } \\
\text { development } \\
\text { in the regions }\end{array}$ & $\begin{array}{l}\text { - Uniform representation of the number of SMEs in the regions, taking } \\
\text { into account the population; } \\
\text { - annual increase in the number of regions in which the basic } \\
\text { infrastructure for supporting SMEs is formed; } \\
\text { - annual increase in the number of regions in the territory of which } \\
\text { services are provided to SMEs on a "one-stop-shop" basis; } \\
\text { - annual increase in the number of cities covered by the SME business } \\
\text { navigator portal }\end{array}$ \\
\hline $\begin{array}{l}\text { Qualitative } \\
\text { growth of } \\
\text { SME business }\end{array}$ & $\begin{array}{l}\text { - An annual increase in the number of technologically complex } \\
\text { industries in which there is an increase in the number of SMEs; } \\
\text { - annual increase in demand for SME products in the domestic market; } \\
\text { - annual increase in the number of embedded SMEs in the supply chain; } \\
\text { - annual growth of SMEs receiving annual profits; - annual increase } \\
\text { in the number of enterprises representing microbusinesses that have } \\
\text { switched to small or mediumsized businesses; } \\
\text { - annual growth of markets for SME products; - annual increase in the } \\
\text { share of expenses of SMEs on investments in their development }\end{array}$ \\
\hline $\begin{array}{l}\text { Further } \\
\text { training for } \\
\text { SME staff }\end{array}$ & $\begin{array}{l}\text { Annual increase in the number of trained people (and advanced } \\
\text { training) from among representatives of SMEs; - annual increase in } \\
\text { the number of trainings conducted on training programs for SMEs; } \\
\text { annual increase in the number of SMEs connected to the federal } \\
\text { educational platform }\end{array}$ \\
\hline $\begin{array}{l}\text { State } \\
\text { participation } \\
\text { in the } \\
\text { development } \\
\text { of SMEs }\end{array}$ & $\begin{array}{l}\text { Annual increase in the number of applications from SMEs for the } \\
\text { expansion of activities fully satisfied by local governments; } \\
\text { - annual increase in the share of fairs with the participation of SMEs }\end{array}$ \\
\hline
\end{tabular}

At present, in our opinion, the task is to ensure the sustainability of the SME business in order to create an effective layer of such a sector in Russian economy for the long term. At a faster pace, this can be realized by fixing the corresponding target indicators in the long-term planning document - the Strategy. We have proposed indicators that can be targeted, reflecting groups on 
the infrastructure development of SMEs, the development of SMEs in the regions, the qualitative growth of SME business, the advanced training of SME staff, as well as state participation in the development of SMEs. The next stage would be setting of the target values of that indicators.

\section{REFERENCES}

[1]. Report of the Ministry of Economic Development of Russia "On measures for the development of small and medium-sized enterprises". Available at: http:// economy.gov.ru/wps/wcm/ connect/3c7df252-62cc-4a3cbdfb $-4 \mathrm{c} 3909 \mathrm{a}-$ $9 \mathrm{~d} 7 \mathrm{a} 0 /$ Doklad+\%D0\%BA+\%D0\%93\%D0\%A1_7+\%D0\%B0\%D0\%BF\% D1\% 80\% D0\% B5\% D0\% BB\% D1\% 8F \% D1\% 84\% D0\% B8\% D0\% BD\% D0\% B0\% D0\% BB.pdf? MOD = AJPERES \& CĀCHEID = 3c7df252-62cc-4a3c-bdfb- 4c3909a9d7a0.

[2]. Report of the Ministry of Economic Development of Russia "On the results achieved to improve the conditions for doing business, developing small and medium-sized businesses and supporting individual entrepreneurial initiatives. Available at: http://economy.gov.

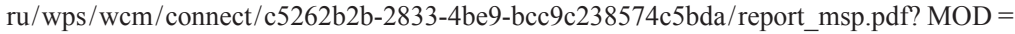
AJPERES \& CACHEID = c5262b2b-2833-4be9-bcc9-c238574c5bda.

[3]. Doing Business project. Available at: http://Russian.doingbusiness.org

[4]. Report of the SME Corporation "On the results of a study on the status and development of SMEs in the Russian Federation, the results of measures to support it, and the development of an estimated forecast for its development". URL: https://corpmsp.ru/about/deyatelnost/monitoring-okazaniya-podderzhkisubektam-msp/rezultati_issledovaniya/

[5]. Report of the SME Corporation "On the implementation of the priority project "Small business and support of individual entrepreneurial initiative in 2017". Available at: https://corpmsp. ru/upload/iblock/18e/\%D0\%9E\%D1 \%82\%D1\%87\% D0\% B5\% D1\% 82\% 20\% D0\% BE\% 20\% D1 \% 80\% D0\% B5\% D0\% B0\% D0\% BB\% D0\% B8\% D0\% B7\% D0\% B0\% D1 \% 86\% D0\% B8\% D0\% B8\% 20\% D0\% BF\% D1 \% 80\% D0\% B8\% D0\% BE\% D1 \% $80 \%$ D0 \% B8\% D1 \% 82\% D0\% B5\% D1 \% 82\% D0\% BD $\%$ D0\% BE\% D0\% B3\% D0\% BE $\%$ 20\% D0\% BF\% D1 \% 80\% D0\% BE\% D0\% B5\% D0\% BA\% D1 \% 82\% D0\% B0\% $20 \%$ D0\% B7\% D0\% B0\% 202017\% 20\% D0\% B3\% D0\% BE\% D0\% B4.pdf

[6]. http://economy.gov.ru/minec/about/structure/depmb/201807021.

[7]. Strategy for the development of small and medium-sized enterprises in the Russian Federation for the period until 2030. URL: http://economy.gov.ru/wps/wcm/connect/b0e8d641-c6f8-4edb-b9c0d5681930aa3c/strategMSP.pdf?MOD= AJPERES \& CACHEID = b0e8d641-c6f8-4edb-b9c0-d5681930aa3c.

[8]. National rating of the investment climate in the constituent entities of the Russian Federation. URL: https://asi.ru/investclimate/rating/

[9]. The official website of the Government Commission on Competition and the Development of Small and Medium Enterprises. URL: http:/government.ru/department/132/about/

[10]. The official website of the Federal Corporation for the Development of Small and Medium Enterprises (SME Corporation). URL: https://corpmsp.ru/.

[11]. URL: http://government.ru/docs/21742/.

[12]. Gantseva L.V. Strategic trust as an instrument of crisis management, Management of economic systems, 2018, no 4. Available at: http://uecs. ru/finansi-i-kredit/item/4853-2018-04-12-11-11-09-12. 